\title{
Dosztojevszkij hatása Pilinszky János kárhozatról szóló elmélkedéseiben
}

Jean-Paul Sartre Férfikor címú regényére reflektáló esszéjében Pilinszky (1999. 118-119.) a következóket írja: „A pokol titka: a semmi titka, az élet örömeinek és szenvedéseinek megtagadása. A mennyek titka viszont a szeretet titka. Az élet örömeinek és szenvedéseinek vállalása. A semmi titkával a teremtés titka, a megsemmisülés titkával a szereteté áll szemben. Legszebb modern ábrázolását e küzdelemnek Dosztojevszkij irta meg a Karamazov testvérekben-ben, a rejtélyesen elmagányosodott Iván és a titokzatosan nyitott Aljosa ellentétében. Iván körül a semmi müvei és tettei, amelyek mindig többet mutatnak, mint a mögöttük tátongó üresség, míg Aljosa igénytelen s alázatos cselekedetei mögött a hatalmas és kifogyhatatlan többlet hallgat, mintha a teremtés egyedül a szeretetben válna érvényessé, bírná és kívánná csak igazán megvalósitani, betetôzni önmagát. Szeretet híján a valóság a semmibe hanyatlik vissza."

$\mathrm{E}$ sszéiben Pilinszky az üdvösség szempontjainak meglehetősen pontos körvonalazásához képest kevésbé törekedett a kárhozat problémájának konkrét módon történő tisztázására. Annál inkább érzékelhető azonban ez a törekvés szépprózai írásainak némelyikében, ahol vagy fiktív szereplőkkel mondatja ki, vagy valós személyek fiktív párbeszédébe ágyazva interpretálja definíciószerü téziseit. A Hármasoltár három részében különböző történetek épülnek egymásba oly módon, hogy a szereplők cselekedetei egy bibliai jelképrendszer szerint értelmeződnek. Tolcsvai Nagy Gábor (2002. 173.) szerint e prózabeli szerkezetek egyik legfőbb jellemzője, hogy úgy részletezik az összetevőket és úgy alakítják az implicit olvasót, hogy közben a megértés feltételei egyszerre maradnak hermetikusak és túlzottan körülírtak, vagyis rejtélyesek a véges evilágit illetően és túlmagyarázottak a transzcendenst illetően. A harmadik szövegben például egy kárhozatra vonatkozó, dogmatikailag nehezen értelmezhető hitvallást ad a címszereplö, Ónix Beáta szájába: „Az elkárhozásban nem hiszek, de a pokolban igen. A semmi és a valóság között fekszik egy óriási tenger, a mintha sugárhatású holt vize, s ennek a partján, ennek a visszfényében élünk, mi, emberek." (Pilinszky, 1996. 197.) A Dosztojevszkijnek ajánlott szöveghez kapcsolható kiegészítésként a két évvel korábbi, Középút és középszer című cikkben szereplő gondolat, amelyben Pilinszky épp a nagy orosz íróra hivatkozva próbálja leírni a pokol lehetőségében rejlő „mintha-lét” természetét, egy másik fogalom, a „középszerüség” felől közelítve a problémához: „Dosztojevszkijnek igaza volt, amikor 
az ördögöt közönségesnek vélte. És ha az ördög csakugyan közönséges, a pokol minden bizonnyal középszerü. Kilátástalanul és reménytelenül középszerü." (Pilinszky, 1999. 745.) A Hármasoltár idézett részletének bevezető mondata viszont („Az elkárhozásban nem hiszek, de a pokolban igen.") azért problematikus, mert a kárhozat dogmájához hű teológiai elképzelésként éppen az ellenkezője volna csak elfogadható. Varillon szerint például pokol csak akkor van, ha kárhozottak is vannak. Olyan pokol nincs, amely az elkárhozás állapotától függetlenül létezne (Varillon, 2001. 190.). Valószínüsíthető ugyanakkor, hogy a ,pokol” itt nem egy „túlvilági” tartomány vagy állapot megjelöléseként, hanem az evilági „mintha-lét” metaforájaként szerepel.

A Hitünk „,iskolája” címü, 1967-ből származó esszé megállapítása szerint ,az a bünös, ki már nem is szenved bünei terhétöl, tulajdonképpen már itt a földön a kárhozat állapotában leledzik" (Pilinszky, 1999. 504505.). Ez a mondat arra a teológiai alapigazságra utal, amely szerint a kárhozat (más biblikus kifejezéssel a „második halál”) csupán lehetséges halála mindazoknak, akik annyira bezárkóztak saját önzésükbe, hogy képtelenek megnyílni a szeretetre. Ez az állapot tehát már ,itt a földön” olyan helyzetet teremthet számukra, amelyet a Pilinszky által említett hagyomány értelmében nyugodtan nevezhetünk kárhozatnak. ${ }^{1}$ Itt ugyan Pilinszky nem tér itt külön arra, hogy az örök kárhozat dogmatikai valósága a tétel értelmében csak azokra vonatkozik, akiket a különítélet megátalkodva talál a halálos bün állapotában, de egyéb szövegei tanúságának fényében feltételezhető, hogy gondolkodásában az általa „,keresztény realizmus”-nak ${ }^{2}$ nevezett álláspont nem a kárhozat valóságával, hanem csupán a kárhozat lehetőségével áll szemben.

Habár a keresztény eszkatológiához kiiktathatatlanul hozzátartozik a végérvényes bukás lehetősége, az örök kárhozatról való beszéd képezi talán e teológiai traktátus legnagyobb terhét. Természetesen a pokolra vonatkozóan is figyelembe kell venni az eszkatológiai kijelentések hermeneutikájának általános szabályait, ám mindvégig szem előtt kell tartani a tényt, hogy egy nehezen közölhető hittételről van szó, amely gondolatilag nem világítható meg hiánytalanul
A Hitünk „iskolája” címú, 1967ból származó esszé megállapítása szerint „az a búnös, ki már nem is szenved bünei terhétól, tulajdonképpen már itt a földön a kárhozat állapotában leledzik" (Pilinszky, 1999. $504-$ 505.). Ez a mondat arra a teológiai alapigazságra utal, amely szerint a kárhozat (más biblikus kifejezéssel a „második halál") csupán lehetséges halála mindazoknak, akik annyira bezárkóztak saját önzésükbe, hogy képtelenek megnyílni a szeretetre. Ez az állapot tehát már „itt a földön” olyan helyzetet teremthet számukra, amelyet a Pilinszky által emlitett hagyomány értelmében nyugodtan nevezhetünk kárhozatnak. Itt ugyan Pilinszky nem tér itt külön arra, hogy az örök kárhozat dogmatikai valósága a tétel értelmében csak azokra vonatkozik, akiket a különitélet megátalkodva talál a halálos bún állapotában, de egyéb szövegei tanúságának fényében feltételezhetó, hogy gondolkodásában az általa ,keresztény realizmus"-nak nevezett álláspont nem a kárhozat valóságával, hanem csupán a kárhozat lehetôségével áll szemben. 
(Scheffczyk és Ziegenaus, 2008. 173.). A dogma szövegében azonban rendkívül lényeges a „megátalkodva” kifejezéssel jelölt kitétel. Ahhoz ugyanis, hogy valaki elkárhozzék, az szükséges, hogy az illetöt ez a döntés lényegében kötelezze el. A maximális hajtóerejéig fokozott bün azt a személyes és tudatos döntést foglalja magában, amely megsemmisíti önmaga számára még Istennek a szeretetét is. ${ }^{3}$

A Karamazov testvérekben Dosztojevszkij az alábbi gondolatokat adja regényalakja, Zoszima sztarec szájába: „Atyáim és mestereim, azon gondolkozom: »Mi a pokol?« És így vélekedem: »Szenvedés amiatt, hogy nem lehet többé szeretni.« [...] Ó, vannak, akik a pokolban is kevélyek és szilajak maradtak, noha most már kétségtelenül tudnak mindent, és világosan látják a megcáfolhatatlan igazságot; vannak olyan szörnyetegek, akik mindenestül odaadták magukat a sátánnak. Ezek számára a pokol immár önként vállalt létforma, mellyel nem tudnak betelni. Ezek már önszántukból szenvednek. Mert az Istent és az életet elátkozva, önmagukat átkozták el.” (Dosztojevszkij, 2004. 406-407.)

Pilinszky 1980 decemberében és 1981 márciusában két azonos című cikket közölt az Új Emberben, és mindkettőben Zoszima tanításait széljegyzetelte. ${ }^{4}$ Egy Töröcsik Marinak írt levele éppen ebből az időszakból származik, és megerősíti azt a feltételezést, amely szerint a regényben felmerülő végső állapotokra vonatkozó kérdések foglalkoztatták ekkor leginkább a költőt: „Újraolvasom a Karamazovokat; döbbenetes! Pártatlanul száll alá három alaptípus - a szent, a lázadó és a képmutató lelke mélyére - egy, a Dante dimenzióit sokszorosan meghaladó mennybe, purgatóriumba és pokolba, egyszóval önmagába és persze az olvasóba. Valamikor azt hittem, hogy ismert »fecsegése« zseniális formai találmánya volt. Most ámulva látom, hogy sohase fecseg, minden rezdülése pontos megfelelője egy örökmozgásban lévő drámának. Szerb Antal (amikor először és utoljára fölkerestem) azt mondta, már egyedül ezt a regényt tudja olvasni. Minden huszadik századi mütől az különbözteti meg, hogy hasonlíthatatlan erejét tökéletesen földeli, a pokolban is szelíd marad." (Pilinszky, 1997. 435.)

A Pilinszky-féle „keresztény realizmus” a dosztojevszkiji megközelítéssel párhuzamosan azt az állítást tartalmazza tehát implicit módon, hogy a kárhozat nem lehet az üdvtörténet, valamint a végső események és állapotok sorába illeszthető, azokkal egy szinten lévő realitás, hanem csak ezek negációjaként, vagyis a beteljesülés kudarcának lehetőségeként manifesztálódhat. Pilinszky úgy gondolja - amint azt A különös szféra címü rövid elmélkedésében olvashatjuk -, hogy a bünben való megátalkodottságot elsősorban az erény képében tetszelgő farizeusi magatartás hordozza magában: „A kegyelem és az alázat szférájában lényegében »bün és erény« egyformán szolgálhatja fölemelkedésünket, mivel az alázatos szívben Isten mindent, még a bünt is jóra fordítja, míg az alázat nélkül az »erény« sem ér semmit, sőt vesztünket okozhatja." (Pilinszky, 1999. 602.) Az alázat nélküli erény éppen azért lehet a megátalkodottság forrása - következtet Pilinszky -, mert az állhatatossággal ellentétes víciumként kizárja a megtérés és a gyógyulás lehetőségét.

Az idézett szöveg után két héttel megjelent Viszonyunk a farizeushoz címü írásában szerepel ugyan a „farizeus” kifejezés, de nyilvánvalóan nem az evangéliumokból is jól ismert vallási csoportot jelöli vele, hanem a fent körvonalazott magatartásformát. Pilinszky itt azt hangsúlyozza, hogy (az üdvösség szempontjából) az önmagával való szembenézésre képtelen ember helyzete a tulajdonképpeni „megoldhatatlan eset” (Pilinszky, 1999. 603.). A világgal szembeni ,ítélkező és indiszkrét”, farizeusi magatartásforma az a meghasonlott (vagy megátalkodott) bünös állapot, amely a kárhozat elvi lehetőségét magában foglalja. Ennél Pilinszky (hittani szempontból) nem is mond többet. Levél a ,diszkrécióról” című cikkében azonban már nemcsak harmadik személyben beszél róluk, az előzőhöz hasonló kontextusban, hanem egy saját magunkkal szembeni lelki beállítottságra is ösztönöz: „Az indiszkrét lélek átvilágíthatatlan. $\mathrm{S}$ bár róla írva jogosan mindenkire gondolok, mégis tudom, hogy valóságosan is létezik, de soha senki 
halandó embernek nem szabad, nincs joga konkrétan megnevezni őt. ${ }^{5}$ Ember egy másik ember bünét sose nevezheti meg rámutatva a bünösre. Igaz, az indiszkrét lélek épp ezt nem tudja, nem tudhatja, mivel épp ez az a pont, ahol Isten útjai kezdődnek." (Pilinszky, 1999. 805.)

Ebből a részletből az olvasható ki, hogy Pilinszky szerint a kárhozat lehetőségével számolnunk kell ugyan, de kizárólag önmagunk számára, hiszen ha az ember „egy másik ember bünét sose nevezheti meg", akkor a másik esetleges elkárhozásáról sem beszélhetünk. Éppen ezért elengedhetetlen a bünbánat, és ezért szorul rá mindenki Isten irgalmára. Párizsi filmlevél címü írásában abból a tényből indul ki, hogy a jó müvészetben azért nem maradhat semmi sem elszigetelt, speciális jelenség, mert az ábrázolt emberi sorseseményeket a szerző mindig egyetemessé avatja. „Dosztojevszkij Raszkolnyikovja ezért nem azonos a ponyvatermék és az újságcikk gyilkosával. Raszkolnyikov te vagy, és én vagyok, annak ellenére, hogy se te, se én nem öltünk embert" - írja (Pilinszky, 1999. 651.). Ha viszont továbbra is fenntartjuk azt a premisszát, hogy a büntetés nem Istentől, hanem magából az emberből jön - a halálos bünbe való „,beleragadás” (megátalkodottság) következményeként -, akkor a következő problémával állunk szemben: úgy tünik, hogy Isten (mindenható) szeretete nem tehet semmit a kárhozat eshetőségével szemben; ahogyan ezt Pilinszky Lukács margójára címú írásában megfogalmazza: „Minden szeretet tragikus; nincs szeretet tragédia nélkül. És Istennek még csak választása sincs, hogy elfogadja a szeretetet, vagy elutasítsa a tragédiát, mivel ő maga a szeretet." (Pilinszky, 1999. 593.)

A kárhozat lehetőségére vonatkozó, Pilinszkynél olvasható két ellentétes feltevés tehát - egyrészt az, hogy a saját bünei terhével szemben közömbös ember (képletesen szólva) már itt a földön a kárhozat állapotában leledzik, másrészt pedig az, hogy nincs olyan bün, amely véglegesítené bárki élő halálos lelkiállapotát - párhuzamosan, de eltérő hangsúlyokkal van jelen Pilinszky gondolkodásában. Az egyház szisztematikus reflexiójában is azt látjuk, hogy az egymással dialektikusan szembeállított két kijelentés nem ugyanazon a szinten mozog. A keresztény emberről azt állítjuk, hogy hisz a mennyben, de (legalábbis a „hinni” szónak ugyanabban a jelentésében) semmiképpen sem állíthatjuk, hogy hisz a pokolban. A hit ugyanis remény, méghozzá mindenkiért. A kárhozat így csupán egy lehetőség marad (Nocke, 1997).

A kárhozat elvi lehetőségének és lehetetlenségének dilemmájából következik az egyetemes üdvösség kérdése. Szembetünő a különbség Pilinszky és Dosztojevszkij megközelítése között, mert míg Pilinszky mindenekelött a farizeusi magatartásban látja a kárhozat elvi lehetőségét, addig Dosztojevszkij az öngyilkosságot emeli ki ezzel kapcsolatban. A Karamazov testvérek vonatkozó részében (ismét Zoszima tanításáról van szó) a következőket olvashatjuk: „Hanem jaj azoknak, akik saját maguk pusztították el magukat a földön, jaj az öngyilkosoknak! Én úgy vélem, hogy ezeknél szerencsétlenebb nem is lehet senki. Figyelmeztetnek bennünket, hogy vétek ezekért könyörögni az Istenhez, és az egyház is mintegy kiveti őket, de én lelkem rejtekében úgy gondolom, hogy öértük is lehet imádkozni. Hisz a szeretet miatt nem haragszik meg Krisztus. Én egész életemen át imádkoztam magamban az ilyenekért, és bevallom nektek, atyáim és tanítómestereim, még mostanában is mindennap imádkozom." (Dosztojevszkij, 2004. 406.)

A dogmatörténeti fejlődés azt mutatja, hogy a Dosztojevszkij által érintett kérdés nagy hagyományra tekint vissza. A pokol örökkévalóságáról szóló többségi elképzeléssel szemben áll néhány jelentős teológus (Alexandriai Szent Kelemen, Órigenész, Nüsszai Szent Gergely stb.) véleménye, akik az apokatasztaszisz pantónt, vagyis az elkárhozottak (sőt néhányan az ördög) megmentését tanították. ${ }^{7}$ Az újabb korban Hans Urs von Balthasar az egyetemes üdvösség tanának legeredetibb képviselője, aki bár érezhető szimpátiával viseltetik a tan ókori képviselői iránt, ${ }^{8}$ egyértelműen visszautasítja, hogy ő 
maga apokatasztasziszról beszélne, és nyomatékosan hangsúlyozza, hogy egész teológiai érvelése pusztán a mindenkit megillető remény igazolására törekszik (Scheffczyk és Ziegenaus, 2008. 169-170.). Az ő elgondolását füzi tovább François Varillon, aki szerint az elkárhozás lehetősége (mint a szeretet feltétel nélküli elutasítása) bele van írva magának az emberi szabadságnak a struktúrájába. A pokol lehetősége így (paradox módon) divinizálható szabadságunk egyik strukturális eleme. A pokol dogmája tehát mindenekelött egy olyan lelki beállítottságra tanít bennünket, amely az imává formált reménység fenoménjában ragadható meg ellentmondásmentesen (Varillon, 2001. 191-193.).

Inkább ösztönösen, mintsem tudatosan, ám mindvégig következetesen tartózkodik Pilinszky is az apokatasztaszisz-tan szélsőségétől. Megközelítése inkább az említett balthasari-varilloni remény-teológiához hasonló, és egyértelmüen látszik, hogy bármilyen kontextusban fordul elő a kárhozat témája, megfontolt érvei mindig azt a célt szolgálják, hogy amennyiben a két álláspont - a faktuális és a potenciális kárhozat-interpretáció - közötti feszültség felszínre kerül, lehetőleg az utóbbi irányába billenjen el a mérleg. És ez nagyrészt bizonyára dosztojevszkiji hatás. Keresztről keresztre címü írásában ez áll: „Bízzunk benne, hogy az Atya, mindannyiunk Irgalmas Istene, ezt a végső pillanatig fönntartott, kifeszitett ellentmondást, békétlenséget és meghasonlást, ezt a fanatikus megosztottságot is ellenállhatatlan kegyelmébe fogadta, mindennel és mindenkivel egyesítette az ő isteni békéjében, és nem engedte át a mindent és mindenkit kirekesztő semminek. Hinnünk kell, hogy Isten egyenesen elvárja tölünk, hogy egyetlen bal latorról se feledkezzünk el. Erre Jézus a példánk. Igaz, barátságába fogadta a jobb latrot, de egyetlen ítélkező szava se volt a bal latorhoz. Kihülő és elnémuló ajka egyetlen nagy imádság volt - valamennyiünkért."

Az idézett szövegek vonalvezetése azt mutatja, hogy a Pilinszky által preferált vallásos viszonyulás egyáltalán nem iktatja ki a pokol rettenetes valóságát, ám az egyetemes reményt mint jelzőfényt állítja elénk. Az a lelki magatartás (vagy lelki érték), amelyet a pokol dogmája megkövetel, és amely az egyetlen lehetséges kiút a felvázolt dilemmából, akárcsak Dosztojevszkijnél, Pilinszky esetében is az imává formált reménység.
Inkább ösztönösen, mintsem tudatosan, ám mindvégig következetesen tartózkodik Pilinszky

is az apokatasztaszisz-tan szélsóségétól. Megközelitése inkább az emlitett balthasarivarilloni remény-teológiához hasonló, és egyértelmúen látszik, hogy bármilyen kontextusban fordul elö a kárhozat témája, megfontolt érvei mindig azt a célt szolgálják, hogy amennyiben a két álláspont - a faktuális és a potenciális kárhozat-interpretáció közötti feszültség felszinre kerül, lehetóleg az utóbbi irányába billenjen el a mérleg. És ez nagyrészt bizonyára dosztojevszkiji hatás. Keresztról keresztre címú irásában ez áll: „Bizzunk benne, hogy az Atya, mindannyiunk Irgalmas Istene, ezt a végsó pillanatig fönntartott, kifeszitett ellentmondást, békétlenséget és meghasonlást, ezt a fanatikus megosztottságot is ellenállhatatlan kegyelmébe fogadta, mindennel és mindenkivel egyesitette azó isteni békéjében, és nem engedte át a mindent és mindenkit kirekesztó semminek. 
Ez a remény pedig más és több mint biztos vagy akár csak valószínű előrejelzés, hiszen a cselekvésre irányuló akaratot is magában foglalja (Nocke, 1997). Mivel nem a rendszer semleges logikájából fakad, nem válik önkényes állítássá, hanem - ahogy Ratzinger (2017. 226.) írja - „kérő fohászát belehelyezi az Úr kezébe s ott is hagyja. A dogma megőrzi valós tartalmát; az irgalmasság gondolata, amely így vagy úgy, de végigkísérte azt a történelem egész folyamán, nem válik elméletté, hanem a szenvedő és remélő hit imája lesz belöle."

\section{Irodalom}

Balthasar, Hans Urs von (2006). Mit szabad remélnünk? Rövid értekezés a pokolról. Apokatasztaszisz. Ford. Görföl Tibor. Sík Sándor Kiadó.

Dosztojevszkij, F. M. (2004). A Karamazov testvérek. I. kötet. Ford. Makai Imre. Jelenkor.

Nocke, F.-J. (1997). Eszkatológia. In Schneider, Th. (szerk.), A dogmatika kézikönyve. II. kötet. Ford. Válóczy József. Vigilia.

Pilinszky János (1996). Széppróza. Osiris.

Pilinszky János (1997). Pilinszky János összegyüjtött levelei. Osiris.

Pilinszky János (1999). Publicisztikai írások. Osiris.

Ratzinger, J. - XVI. Benedek pápa (2017). Végidő. A halál és örök élet kérdései. Ford. Török Csaba. Jel.
Scheffczyk, L. \& Ziegenaus, A. (2008). Katolikus dogmatika VIII. A teremtés jövöje Istenben. Eszkatológia. Ford. Szalay Mátyás. Szent István Társulat.

Schütz Antal (1937). Dogmatika. II. kötet. Szent István-Társulat.

Szmeskó Gábor (2020). A távolság közelében I. Simone Weil hatása Pilinszky János misztikafogalmára. Forrás, 52(4), 97.

Tolcsvai Nagy Gábor (2002). Pilinszky János. Kalligram.

Varillon, F. SJ (2001). A hit öröme az élet öröme. Konferenciabeszédek a keresztény hit föbb kérdéseiröl. Ford. Kaposiné Eckhardt Ilona. Márton Áron.

\section{Jegyzetek}

${ }^{1}$ Ennek a megállapításnak természetesen semmi köze nincs a szadduceizmus álláspontjához, amely tagadja a „túlvilágot”, és a végső eseményeket, illetve állapotokat a jelen világba helyezi (vö. Schütz, 1937. 641.). A jelen élet potenciális kudarca és a végérvényes bukás lehetősége közötti összefüggés abban az üdvösségre vonatkozó, de az üdvösség elvesztésével kapcsolatban is alkalmazható tényben világítható meg, amely szerint az örök élet nem felváltja a földi életet, hanem már benne megkezdődik, és nem helyettesíti, hanem beteljesíti azt. A fenti szövegben ez a gondolat jut kifejezésre.

${ }^{2} \mathrm{Azt}$, hogy egészen pontosan mit is ért keresztény realizmus alatt, Jézus utolsó két szava című cikkében tárja fel részletesebben: „A keresztény realizmus gondolatmenete a következő: Aki becsületesen felméri a világgal, önmagával és Istennel szemben való reményeit és föladatait, kétségbe kell hogy essék önmaga gyarlósága, megbízhatatlansága felett. Ez a kétségbeesés azonban nem szükségszerủen negatív előjelü, sőt úgy is tekinthetjük, mint a szellemi felnőttség, a keresztény realizmus kezdetét. Nem záróköve tehát, hanem nyitánya a tulajdonképpeni fölemelkedésnek. Ilyen értelemben: nincs nélküle valóság. Viszont: csak küszöbe annak, és nem szíve. Megmaradni benne ezért bűn, negatív, irreális, diabolikus állapot. Nem megtapasztalása többé a valóságnak, hanem megsemmisítése.” (Pilinszky, 1999. 349.) Szmeskó Gábor - aki külön is foglalkozott e kérdéskörrel - kutatásai szerint a keresztény realizmus fogalmát Pilinszky döntően 1961 és 1964 között használta (vö. Szmeskó, 2020. 97.).

${ }^{3}$ Ez a megállapítás abszurdnak tünhet önmagában, hiszen Isten szeretetét lehetetlen megsemmisíteni. Az embernek azonban hatalmában áll megsemmisíteni azt önmaga számára, mint ahogyan megsemmisítheti önmaga számára az oxigént, ha abbahagyja a lélegzést, vagy ahogyan megsemmisítheti önmaga számára a napfényt, ha besötétíti a szobát, ahol tartózkodik (vö. Varillon, 2001. 188-192.).

${ }^{4}$ Vö. Pilinszky, 1999. 814-816.; Pilinszky, 1999. 818-819.

${ }^{5}$ Bár itt nem konkrétan a kárhozottakról, hanem a kárhozatra vezető bünről van szó, Pilinszky állásfoglalása teljesen egybevág az egyházéval. Sok emberről nyilvánította ki az egyház, hogy már biztosan üdvözültek, 
vagyis szentként Istennél vannak (ez fejeződik ki az egyház szentté avatási gyakorlatában), ugyanakkor nincs semmilyen összehasonlítható egyházi kijelentés akár csak egyetlen néven nevezett személy elkárhozásáról sem (vö. Nocke, 1997. 490.).

${ }^{6}$ Vö. Nocke, 1997. 490.

${ }^{7}$ Alexandriai Kelemen a halál utáni büntetést inkább orvosságnak tartja, tehát a tisztítótűz értelmében fogja fel, Órigenész pedig az 1Kor 15,24-28 alapján arra következtet, hogy az egész teremtés egyetlen céljához jut el, és ebben az értelemben minden Krisztusnak lesz alávetve, majd átadatik az Atyának, aki mindenben minden lesz. Nüsszai Gergely a büntetést csupán mint a jó és a rossz elválasztását értelmezi (vö. Scheffczyk és Ziegenaus, 2008. 164-165.).

${ }^{8}$ Hans Urs von Balthasar Apokatasztaszisz című írásának második fejezetében az említett egyházatyák tanításából kiindulva summázza az örök kárhozat és az egyetemes üdvösség kérdéséhez kapcsolódó lehetséges álláspontok jellemzőit (vö. Balthasar, 2006. 173-184.).

${ }^{9}$ Pilinszky, 1999. 796. Pilinszky Szabadesés című rövid prózájában szintén oly módon nyúl a Kálvárián játszódó evangéliumi történéshez, hogy a narráció fókuszát a bal lator személyére helyezi („De mi történt baloldalt, ahová senki se figyelt, még János, még Mária, még a farizeusok és a pribékek se?”), bár itt a végső kérdésekről való elmélkedés helyett a jelenet fiktív továbbgondolása dominál (vö. Pilinszky, 1996. 201.). Végkövetkeztetéséröl a protestáns Karl Barth is eszünkbe juthat, aki az ítéletről szóló bibliai gondolatoknak úgy kívánt megfelelni, hogy azokat teljes egészében Jézusra vonatkoztatta. Noha Balthasar a német idealizmus közös filozófiai öröksége miatt számos ponton kapcsolódik Barth teológiájához, ezen a ponton mégis elutasítja azt. Mit szabad remélnünk? című müvében a következőket írja: „Barth az isteni igazságosság és az isteni irgalmasság azonosságát taglalva jut el teológiai célkitűzésének belső középpontjához; de ezután csak egy apró fordulat (Krisztus mindenkiért elkárhozott, hogy az összes kárhozott a mennybe jusson), és máris veszélyesen megközelíti az apokatasztaszisz pantón tételét, ahová már nem követhetjük.” (Balthasar, 2006. 112. o.) 